\title{
Environmental aspects of the theme park development in the Russian Federation
}

\author{
Mariya Tihonova ${ }^{1, *}$, Tatyana Simankina ${ }^{1}$, and Aida Kormishova $^{2}$ \\ ${ }^{1}$ Peter the Great St. Petersburg Polytechnic University, Polytechnicheskaya str., 29, St. Petersburg, \\ 195251, Russian Federation \\ ${ }^{2}$ State University of Management, Ryazansky Prospect, 99, Moscow, Russian Federation
}

\begin{abstract}
Recreation and leisure are of paramount importance in human life. This article makes a comparison of different recreational areas categories. The main focus of this research is the current situation of Russian amusement and theme parks market. A comparison of Russian and European theme parks, their attributes, qualities, popularity and revenue is given. The research uses data gathering, analysis and synthesis to illustrate the insufficiencies of theme park development in the Russian Federation. The completed research suggests that Russia severely lags behind other European countries in terms of theme park quantity and quality. Factors that contribute towards this insufficiency are revealed in the conclusion of this research.
\end{abstract}

\section{Introduction}

The word 'recreation' derived from Latin words: re, meaning 'again'; and creare, meaning 'to create, 'give existence to'. The term seems to stem from 14th-century English language when it was used in the context of 'refreshment or curing of a sick person' [1]. Modern medicine acknowledges the importance of this process for human physical, psychological, and cognitive health.

The importance of recreation and leisure in the life of a modern human is hard to overstate. Stress is a common companion of a modern person because society puts a high value on productivity, which decreases spare time left after work and other daily routines.

Modern media are becoming progressively more engaging, allowing for more enjoyable activities, and 'offline leisure' as it's sometimes called, is struggling to compete. This issue is prevalent among youth especially, as TV and computer games can keep a young person engage for hours on end. These activities are not harmful by themselves, however, when exercised in abundance, they can lead to a number of health-related issues (both physical and psychological), most of which stem from the stationary and solitary nature of these activities. This underlines the importance of forming alternative recreational opportunities and contributed heavily to the emergence of recreational areas.

\footnotetext{
${ }^{*}$ Corresponding author: marie.milson@mail.ru
} 
The importance of this topic lies in the central place recreation takes in human's life. The creation and development of recreational areas can be an answer to the ever-increasing demand for recreation.

Historically leisure has been more available to the upper class, who are more financially capable and have to endure fewer working hours. The advent of technology has enabled long-range travel, which enhanced global tourism. As the average income improves, mode disposable income is being allocated towards tourism and leisure.

Recreation is important for all categories of people, which means that the consumer base of the industry greatly varies in income, interests, lifestyle, and capability to travel. Below is the analysis of recreational areas that can accommodate for a variety of consumer categories.

The biggest tourism market has historically formed in Europe. Most prominent in that regard are Southern and West Europe. Germany has been hosting traditional fares in Hanover, Frankfurt, Leipzig for decades. Since recreational resources are not readily available in every part of the world, more and more people engage in wellness and education travel.

\section{Materials and methods}

This research uses information from open databases on the Internet was used. The sources are linked in text and listed in the "Reference" section of this paper. The subject of this research is recreational areas. For the sake of research, the subject was arbitrarily subdivided into two categories, as explained below.

\section{Temporary recreational areas}

Temporary recreational areas form at the location of mass recreational events. As the name implies, these zones are temporary in nature: they cease to exist when the event ends.

An example is Rio Carnival. The event is held yearly on the streets of Rio de Janeiro, the second most populous municipality in Brazil. In 2019 the event hosted a total of 1.62 million visitors, and amassed over 1.4 billion dollars in revenue [2].

Another example is Oktoberfest, a yearly outdoor festival. This event happens yearly in Munich, Bavaria, Germany and is the most prominent local festival. In 2019 it hosted 6.3 million visitors and generated over 1.3 billion dollars $[3,4]$.

Temporary recreational areas are able to provide a short-term boost to the recreational market of an area, but their temporary nature can make them unavailable for certain population groups. These events are more often than not strongly themed, which decreases the target audience even further.

2. Permanent recreational areas

Permanent recreational areas are stationary in nature and are active for the significant part of the year (except for possible seasonal shutdowns). Examples of such areas are listed below.

Sanya is China's most southern tourist centre and a resort. Located in Hainan province, on an eponymous island, it is China's only tropical resort. With local population of around 700 thousand people, the region accommodated more than 83 million abroad and domestic tourists in 2019. Total tourism revenue is estimated to be 15 U.S. billion dollars yearly [5].

Central Park is an urban park located in the city centre of New York City, U.S. With an area of more than 3,4 square kilometers, it is one of the most visited tourist sites worldwide [6]. Its 65 million dollar budget is being managed by a non-profit municipal organization, The Conservancy. The park is free to enter.

Below is the comparison of amusement and theme parks from different parts of the world. 
Amusement parks are a subcategory of permanent recreational areas. They combine the festive nature of temporary areas but are more accessible to the public due to their permanent nature. They can compete with more traditional tourist locations, like museums and sights, as they allow to target tourists of various age, status, and wealth. Gathering many forms of businesses in one place, they are able to target a wide range of audiences, which helps accommodate whole families in terms of entertainment. They are often huge spectacular facilities that can become a local landmark, Such sites become a go-to place for tourists and secure huge profits. Highly developed regions may have multiple such facilities, which and serve as badges of prestige for the local tourism industry.

Disneyland in Paris, France is a prime example of an amusement park (Fig 1).

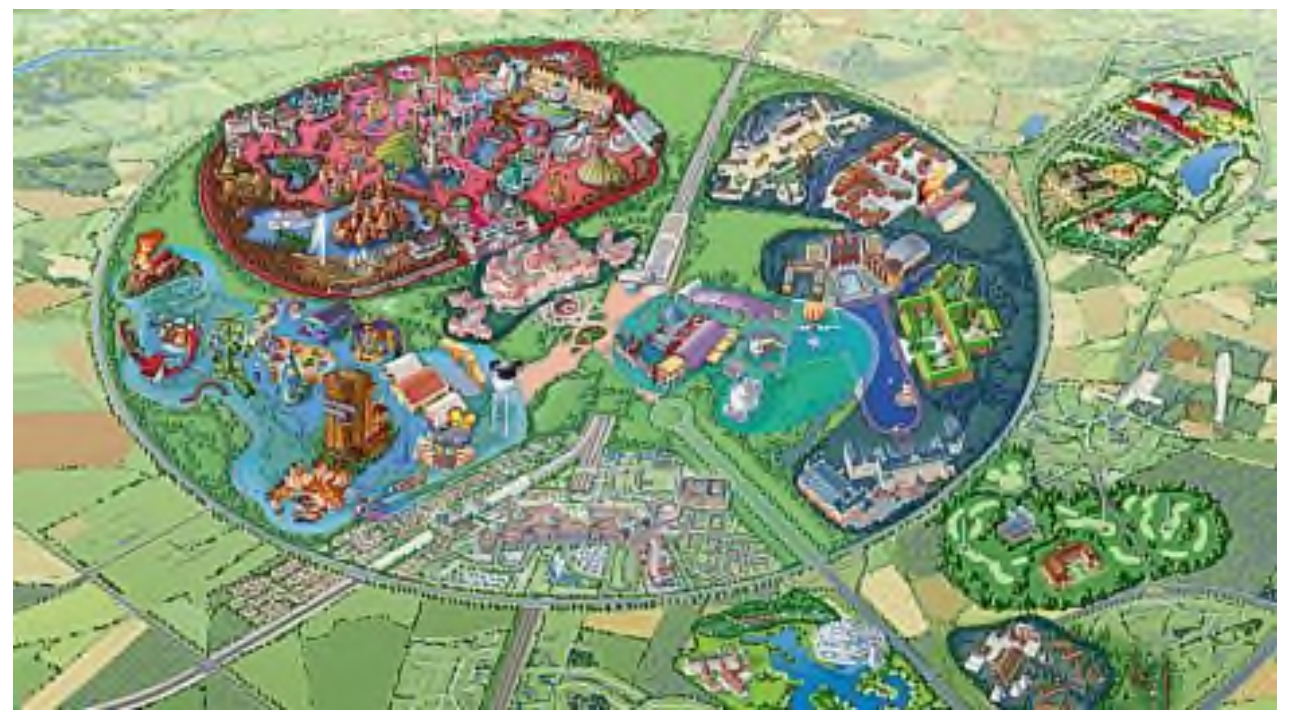

Fig. 2. Disneyland, Paris, France [21].

Disneyland in Paris hosts 2 theme parks, 8 hotels, a golf course, a trading center, and more. The resort hosts a total of 7 roller coasters. Their speeds range from $45 \mathrm{~km} / \mathrm{h}$ on the height of 3 meters (which accommodate for the youngest of guests) to more extreme ones up to $92 \mathrm{~km} / \mathrm{h}, 24$ meters high [7]. Beyond entertainment, the resort features a massive outlet center, «Val d'Europe» which contains 190 shops and 30 restaurants. Spanning over 1 million square feet, it's the most lucrative attraction for every shopper.

Disneyland Paris had hosted more than 16 million attendants in 2012. At an average price of 50 Euros per ticket, that equates to 800 million Euros in profit from tickets alone. [8] In 2019 however, the number decreased to 9,745 million visitors [9].

Another example of a successful theme park is PortAventura World, located in Salou, a city in Catalonia, Spain. Buit around the PortAventura theme park in 2002, it attracts more than 3,5 million visitors yearly The park contains 9 roller coasters, more than 10 flat and water rides, and 6 themed hotels [10].

In 2013 a 49.9 percent stake at PortAventura has been purchased by a U.S.-based private equity firm for 439 million Euros [11].

The estimated yearly income is around 215 million dollars with 4,85 million yearly visitors $[12,13]$.

\section{The Russian experience}


In terms of recreational areas development, Russia is lagging behind other European countries. The sphere is not developed with only a handful of available examples. Many large and ambitious projects have been stalled by the financial crisis.

An example of a finished such project is Sochi Park. It is built in Sochi, a southern city that is sometimes called the "Russian Riviera". The city hosted the XXII Olympic Winter Games, and multiple matches of the 2018 World Cup, which has bolstered the city's attractiveness among tourists. Considering the visa difficulties. However, the park has to rely on the local resident market. The park features a total of 23 rides, 1 themed hotel. The guests are greeted by famous Russian movie and cartoon heroes like Zmey Gorinych [14].

The Dream Island, another Russian theme park, opened its doors in 29 of February, 2020 [15], (Fig 2). Sometimes referred to as "Russian Disneyland", its estimated construction costs are over 1,5 billion dollars. Featuring a 72 acres glass dome, it's the biggest indoor theme park in Europe.

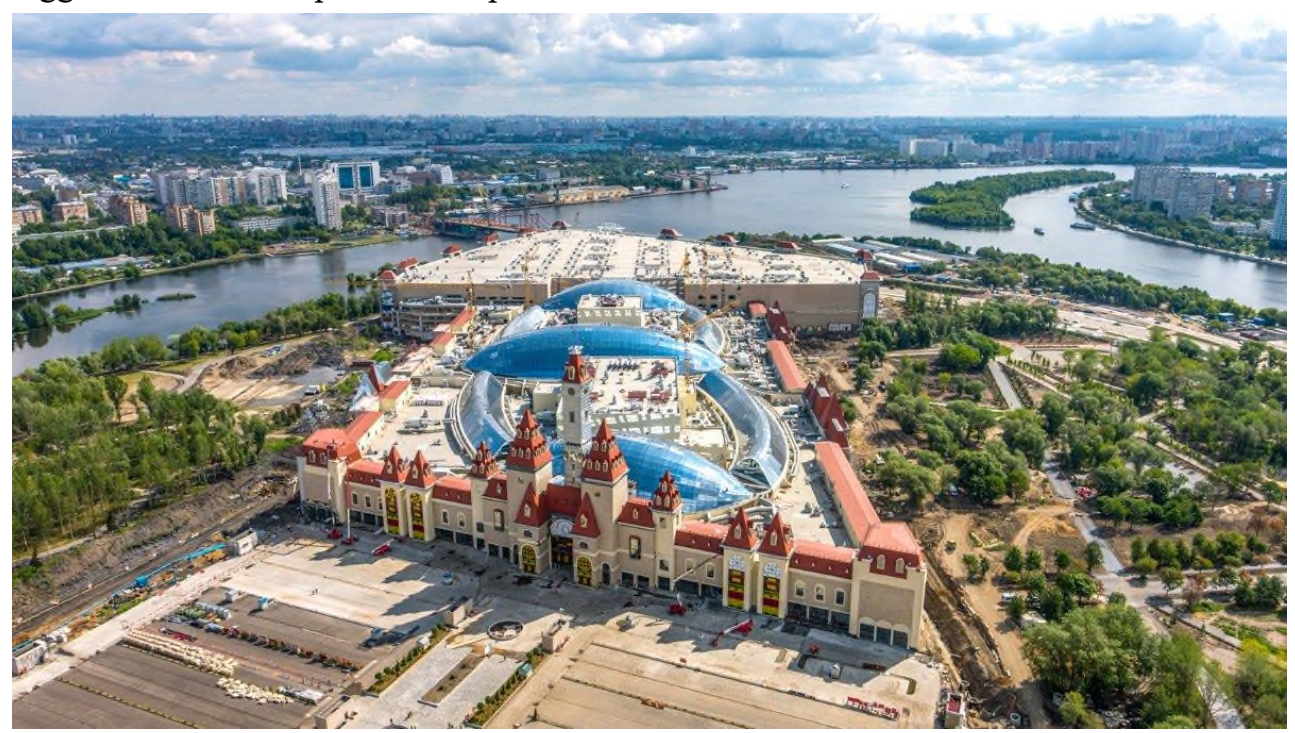

Fig. 2. Dream Island, Moscow, Russia [21].

It features famous cartoon characters like Hello Kitty, Teenage Mutant Ninja Turtles, as well as characters of Soyuzmultfilm, a Russian movie studio. The park is operational all year round, which should help it secure a stable profit. With a price of admission of 163 US dollars for a family of four, it's about twice less expensive to enter than Disneyland Paris [15].

\section{Results and discussion}

The result of the study is a comparison of the selected recreational areas. The comparison is made in table 1.

The comparison shows that even Sochi Park, one of the grandest theme parks in the Russian Federation, fails to capture the financial success and popularity of its counterparts around the world.

Dream Island, a prime Russian theme park can not be found on the lists of most popular theme parks [24]. This fact can be attributed to a relatively high admission price and low value for the price.

Comparison made in table 2 suggests that theme parks in Russian Federation are almost 9 times less prevalent when compared to the rest of Europe. These findings, combined with 


\section{EMMFT-2020}

the decadent popularity figures, reveal the dire situation of theme parks development in the Russian Federation.

Table 2 compares the rate of theme parks to the local population figures in Russian Federation as compared to the rest of European countries.

Table 1. Comparison of the selected recreational areas.

\begin{tabular}{|c|c|c|c|c|c|}
\hline Name & $\begin{array}{l}\text { Area, } \\
\mathrm{km} 2\end{array}$ & $\begin{array}{c}\text { Seasonal } \\
\text { availability }\end{array}$ & Workplaces & $\begin{array}{c}\text { Estimated } \\
\text { yearly } \\
\text { visitors, } \\
\text { million }\end{array}$ & $\begin{array}{c}\text { Estimated } \\
\text { yearly } \\
\text { income, } \\
\text { million } \\
\text { dollars }\end{array}$ \\
\hline \multicolumn{6}{|c|}{ Temporary } \\
\hline $\begin{array}{l}\text { Rio-de-Janeiro } \\
\text { Carnival }\end{array}$ & - & $\begin{array}{l}5 \text { days a year, } \\
1,3 \%\end{array}$ & - & 1,62 & 1400 \\
\hline Oktoberfest & - & $\begin{array}{l}15 \text { days a } \\
\text { year, } 4 \%\end{array}$ & - & 6,30 & 1300 \\
\hline \multicolumn{6}{|c|}{ Permanent } \\
\hline Disneyland Paris & 19 & $\begin{array}{c}\text { Year round, } \\
100 \%\end{array}$ & 17000 & 16 & $>800$ \\
\hline $\begin{array}{l}\text { Port Aventura } \\
\text { World }\end{array}$ & 1,20 & $\begin{array}{l}190 \text { days a } \\
\text { year, } 52 \%\end{array}$ & 2000 [18] & $4,85[16]$ & 215 [17] \\
\hline Sanya, China & 1900 & $\begin{array}{c}\text { Year round, } \\
100 \%\end{array}$ & N/A & 83 & 15000 \\
\hline $\begin{array}{l}\text { New York City } \\
\text { Central Park }\end{array}$ & 3,41 & $\begin{array}{c}\text { Year round, } \\
100 \%\end{array}$ & 350 & 38 & Non-profit \\
\hline Sochi Park & 0,25 & $\begin{array}{l}240 \text { days a } \\
\text { year, } 66 \%\end{array}$ & N/A & $1[18]$ & $33,6[18]$ \\
\hline
\end{tabular}

Table 2. The rate of theme parks to the local population figures in Russian Federation.

\begin{tabular}{|l|c|c|c|}
\hline & $\begin{array}{c}\text { Number } \\
\text { of theme } \\
\text { parks }\end{array}$ & $\begin{array}{c}\text { Population, } \\
\text { million } \\
\text { people }\end{array}$ & $\begin{array}{c}\text { Number of theme parks } \\
\text { per population, } \\
\text { parks/million people }\end{array}$ \\
\hline $\begin{array}{l}\text { Europe (except } \\
\text { Russia) }\end{array}$ & $14[22]$ & $145,9[23]$ & 0,07 \\
\hline Russia & $381[22]$ & $601,3[23]$ & 0,63 \\
\hline
\end{tabular}

\section{Conclusions}

The result of the analysis made in this paper could be interpreted as follows.

Theme parks are a popular form of recreational areas. Theme parks are also capable of attracting massive amounts of tourists, including international tourists. Most successful amusement and theme parks show high revenue figures, surpassing the 1 billion dollar mark in some cases [17].

Unfortunately, Russia is severely lagging behind its European peers in terms of theme parks design and implementation. The research suggests that this development is due to low interest among the population, which is the direct consequence of low design ideas originality and poor final implementation. 


\section{Reference}

1. M. Zhu, J. Gao, L. Zhang, S. Jin, Exploring tourists'stress and coping strategies in leisure travel, Tourism Management 81, 104167 (2020)

2. W.K. Tan, S.Y. Huang, Why visit theme parks? A leisure constraints and perceived authenticity perspective. Journal of Retailing and Consumer Services 57, 102194 (2020)

3. Oktoberfest: folk party with financial clout [Digital source]. - Access link: https://www.ft.com/content/3bb2b534-4246-11e4-9818-00144feabdc0 (Retrieved 14.11.2020)

4. China resort island receives over $83 \mathrm{mln}$ tourists in 2019 [Digital source]. - Access link: http://www.xinhuanet.com/english/2020-01/11/c_138697071.htm (Retrieved 14.11.2020)

5. W.T. Fang, E. Ng, C.M. Wang, M.L. Hsu, Normative beliefs, attitudes, and social norms: People reduce waste as an index of social relationships when spending leisure time, Sustainability 9(10), 1696 (2017)

6. A. Milman, A.D. Tasci, W. Wei, Crowded and popular: The two sides of the coin affecting theme-park experience, satisfaction, and loyalty, Journal of Destination Marketing \& Management 18, 100468 (2020)

7. I.V. Schneider, N.G. Matovnikova, P.V. Samoylenko, Eurasian Union Of Scientists. Theme parks as a form of cultural and leisure activities, Disneyland Attendance Info Yearly attendance figures in millions - The Disneyland Linkage (2020) [Digital source]. - Access link: www.scottware.com.au (Retrieved 12.11.2020)

8. AECOM "Theme Index" [Digital source]. - Access link: https://aecom.com/content/wp-content/uploads/2020/07/Theme-Index-2019.pdf (Retrieved 12.11.2020)

9. Michelle Chenery (2 November 2015). [Digital source]. - Access link: "PortAventura - a world class and versatile events option". (Retrieved 13.11.2020)

10. B. Chang, L. Cheu, D. Elsea, K. LaClair, J. Lock, S. Linford, et.al., AECOM, Global attractions attendance report (2013)

11. I.N. Ostapenko, M.A. Bakumenko, R.S. Usenko, About Some Aspects of Influence of Social Networks on Efficiency of Functioning of Hotel Service of Russia (2020)

12. Annual Report [Digital source]. - Access link: https://s3-eu-west1.amazonaws.com/portaventura-world-productionfiles/wilson_cms/documents/documents/000/010/744/original/2018_Informe-RC-PAEN_baixa.pdf (Retrieved 14.11.2020)

13. İ. Başarangil, Investigation of tourism general environment of Disneyland Paris theme park: A qualitative research, Journal of Tourism and Gastronomy Studies 6(3), 316333 (2018)

14. "Dream Island Park" will open in Moscow in 2019", Izvestia (2018)

15. A.E. Kramer, Russia Gets Its Disneyland, A Cold War Dream Come True. The New York Times (2020)

16. H.N. Abrams, R. Bright, Disneyland: Inside Story (1987)

17. Definition of Theme Park [Digital source]. - Access link: merriam-webster.com. (Retrieved 14.11.2020)

18. Revenue of the tourism and services sector during Carnival in Brazil from 2012 to 2020

[Digital source].

Access

link: 
https://www.statista.com/statistics/974580/carnival-revenue-

brazil/\#: :text=Brazilian\%20Carnival\%3A\%20tourism\%20and\%20services\%20revenu e\%202012\%2D2020\&text=Carnival\%20contributed\%20with\%20around\%207.91,state \%20of\%20Rio\%20de\%20Janeiro (Retrieved 14.11.2020)

19. Number of employees of Port Aventura Entertainment SAU from 2010 to 201 [Digital source]. - Access link: https://www.statista.com/statistics/779396/annual-number-ofemployees-port-aventura/ (Retrieved 14.11.2020)

20. Disneyland Paris Top Tips [Digital source] - Access link: https://joynerjournal.co.uk/2020/03/06/disneyland-paris-top-tips/] (Retrieved 19.11.2020)

21. Island of Dreams park in Moscow [Digital source]. - Access link: https://en.wikipedia.org/wiki/Dream_Island_(amusement_park)\#/media/File:Island_of _Dreams2.jpg (Retrieved 17.11.2020)

22. S.B. Park, J. Kim, Y.K. Lee, C.M. Ok, Visualizing theme park visitors' emotions using social media analytics and geospatial analytics, Tourism Management 80, 104127 (2020)

23. 2019 Revision of World Population Prospects [Digital source]. - Access link: https://population.un.org/wpp/ (Retrieved 25.11.2020)

24. Adult admission price to the most popular theme parks in Europe as of 2018 [Digital source] - Access link: https://www.statista.com/statistics/921444/most-popular-themeparks-in-europe-by-entry-price/ (Retrieved 13.11.2020) 